\title{
Harvest volumes and carbon stocks in boreal forests of Ontario, Canada
}

\author{
by Michael T. Ter-Mikaelian ${ }^{1}$, Stephen J. Colombo ${ }^{1,2}$, and Jiaxin Chen ${ }^{1}$
}

\begin{abstract}
We used models to project forest carbon stocks for a series of harvesting scenarios for 29 boreal forest management units totalling 23.3 million ha in Ontario, Canada. Scenarios evaluated for 2020 to 2050 ranged from a no harvesting option to annual harvesting of $2 \%$ of the total merchantable volume present in 2020. For each scenario, we estimated the following carbon quantities: (a) forest ecosystem carbon stocks, (b) sum of carbon stocks in forest ecosystem and harvested wood products (HWP) minus emissions associated with HWP production and decomposition, and (c) net greenhouse gas (GHG) effects of harvesting estimated as (b) combined with emissions avoided by substituting HWP for non-wood materials. The average of each carbon quantity for 2020 to 2050 was linearly dependent on the annual harvest volume. The developed relationships were used to estimate harvest volumes for which the three carbon quantities would equal equilibrium forest ecosystem carbon stocks for a pre-suppression natural disturbance cycle. These estimates indicate the range of harvest volumes for which resulting carbon stocks would equal or exceed those in an unmanaged forest. Also discussed are possible criteria for determining annual harvest volume.
\end{abstract}

Keywords: forest carbon, managed forest, harvested wood products, emissions

\section{RÉSUMÉ}

Nous avons utilisé divers modèles pour prédire le stockage de carbone forestier avec une série de scénarios de récolte dans 29 unités d'aménagement de la forêt boréale totalisant 23,3 millions d'ha en Ontario, au Canada. Les scénarios évalués de 2020 à 2050 allaient de l'absence de récolte jusqu'à un prélèvement annuel de $2 \%$ du volume marchand total sur pied en 2020. Pour chacun des scénarios, nous avons évalué les quantités de carbone suivantes : (a) le stock de carbone de l'écosystème forestier (b) le stock de carbone total dans l'écosystème et des produits forestiers récoltés (HWP) moins les émissions associées à la production des produits forestiers récoltés et la décomposition, et (c) les effets des gaz à effet de serre (GES) liés à la récolte estimée comme (b) combiné aux émissions évitées en substituant les HWP aux produits non ligneux. La moyenne pour chacune des quantités de carbone pour la période de 2020 à 2050 présentait une relation linéaire avec le volume récolté annuellement. Les équations obtenues ont servi à estimer le volume de la récolte pour lequel les trois quantités de carbone équivaudraient aux stocks de carbone à l'équilibre pour un cycle de perturbation naturelle d'avant suppression. Ces estimations donnent des indications sur les volumes de récolte pour lesquels les stocks de carbone égaleraient ou dépasseraient ceux d'une forêt non aménagée. On discute également de critères potentiels pour fixer la possibilité annuelle.

Mots-clés: carbone forestier, forêts aménagées, produits forestiers récoltés, émissions

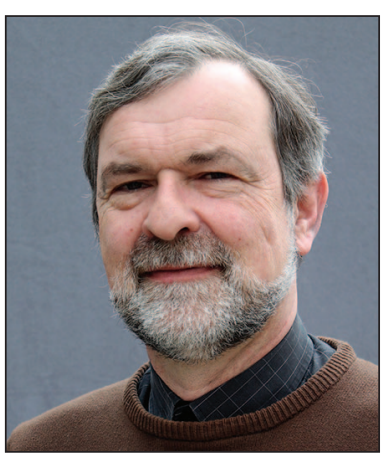

Michael T. Ter-Mikaelian

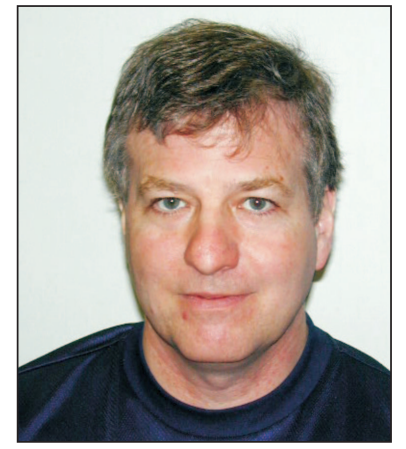

Stephen J. Colombo

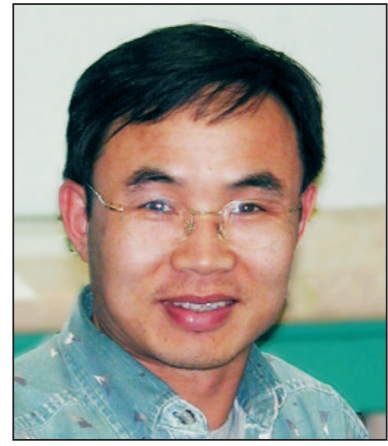

Jiaxin Chen

\footnotetext{
${ }^{1}$ Ontario Ministry of Natural Resources and Forestry, Ontario Forest Research Institute, 1235 Queen St. East, Sault Ste. Marie, Ontario P6A 2E5; Corresponding author's e-mail: michael.termikaelian@ontario.ca

${ }^{2}$ EcoView Consulting, Tecumseh, Ontario
} 


\section{Introduction}

Not surprisingly, forests feature prominently in discussions about climate change mitigation. Forests contain vast amounts of carbon and are a key part of the global carbon cycle (Pan et al. 2011). The unique role of forests stems from the fact that, unlike other sectors of the economy, they can both reduce greenhouse gas (GHG) emissions from other activities and remove and store carbon from the atmosphere (Smith et al. 2014). Consequently, managing forests to maintain or increase their carbon stocks while reducing emissions from them is an integral part of climate change mitigation strategies (Lemprière et al. 2013; Smith et al. 2014).

One of the intuitively appealing approaches used to maintain the amount of carbon stored in forests is managing forest harvesting rates (Böttcher and Lindner 2010). Harvesting removes forest biomass and reduces forest carbon stocks for some period of time. At stand scale, the long-term (averaged over multiple rotations) forest carbon stock decreases with increasing harvesting frequency and the fraction of trees removed each time (Harmon et al. 2009; Nunery and Keaton 2010). A similar effect has been shown at landscape and regional scales, with increased annual harvest volume reducing forest carbon stock (Kaipainen et al. 2004; Depro et al. 2008; Bradford 2011). While the limited number of harvesting scenarios considered might have qualitatively revealed a pattern of "less harvest = more carbon", these studies were insufficient to quantify the relationship between harvest volumes and forest carbon stocks. In addition, representations of carbon in harvested wood products (HWP) were simplified by not including upstream emissions and methane emissions from landfills, using only two categories of HWP (Depro et al. 2008; Bradford 2011), or not considering HWP in landfills (Kaipainen et al. 2004). In the context of climate change mitigation, it is imperative to account for carbon stocks both in the forest and in HWP, along with associated emissions (Kurz et al. 2016). An even more complete consideration of the potential for mitigation by harvested forests would include substitution effects, i.e., reductions in GHG emissions resulting from the substitution of non-wood products with HWP (Kilpeläinen et al. 2016; Kurz et al. 2016; Smyth et al. 2017; Chen et al. 2018a, 2018b).

In Ontario, the guiding principle in forest management is emulation of natural disturbances and landscape patterns, while minimizing adverse effects on ecological, social, and economic values (Statutes of Ontario 1994). These ecological effects are measured in a series of so-called landscape indicators (OMNRF 2014) and inclusion of targets for forest carbon in forest management planning has been discussed (OMNRF 2016). If at some point forest carbon were implemented as a goal of forest management, knowledge of the relationship between harvest volume, natural disturbance, and carbon stocks will be crucial. In this study, we addressed one part of this question by examining the harvesting-forest carbon relationship for a large area of managed forests in Ontario, Canada. Our objectives were to (a) quantify the relationships among carbon stocks for forest ecosystem, HWP, and carbon emissions avoided by substituting HWP for alternative nonwood materials for a given harvest volume, and (b) compare carbon stocks and avoided emissions for historical harvesting (1995-2014) and no harvesting scenarios. We did this for the 2020-2050 period, which is short term but avoids uncertainty associated with longer-term projections. The results shed light on discussions about the role of forests in climate change mitigation by examining how harvesting rate affects carbon stocks and emissions, as well as the net atmospheric GHG effects of the managed forest and HWP.

\section{Materials and methods}

We simulated forest carbon on an area of 23.3 million ha of Ontario Crown (i.e., publicly owned) boreal forests managed for wood fibre (dark-shaded area in Fig. 1). The area is in a province-wide band within north-south limits of about $51^{\circ}$ and $47^{\circ} \mathrm{N}$. The most prevalent forest types are upland and lowland conifer and mixedwood forests. The area's climate, geography, and tree species are described by Watkins (2011). These forests are extensively managed, with human intervention after harvesting ranging from no treatment (i.e., the forest regenerates naturally and regrows without human assistance) to mechanical site preparation with planting and one or two competition control treatments. Thinning is seldom practiced, and, in most instances, regenerated forest is not directly treated before its next harvest, usually eight or more decades later. Suppression of most active fires is standard practice throughout the area.

In Ontario, forests managed for wood fibre are divided into 40 (as of 2020) forest management units (FMUs). The study area included all 29 FMUs classified as boreal forest (OMNRF 2014). These individual FMUs range from about 124150 to 2435900 ha, and collectively include 4.0 million ha (17\% of the total) of forest protected from harvesting (e.g., small parks and other reserves). These FMUs are managed by individual forest companies following regulations set by Ontario's Ministry of Natural Resources and Forestry that aim to ensure forest sustainability (Statutes of Ontario 1994). Note that forest areas in FMUs that are not available for harvesting were included in estimating carbon stocks and harvesting rates (when harvested volume is expressed as the percentage of total merchantable volume in the FMU).

Forestry activities in each FMU are governed by a forest management plan (FMP) that is updated on a ten-year cycle; approved FMPs along with annual reports are accessible from the Ontario Ministry of Natural Resources and Forestry (OMNRF 2020b). Each FMP is based on projections of forest species and ages generated using an optimization planning model, the Strategic Forest Management Model (SFMM; Kloss 2002). This model relies on forest inventory as an input and is used to simulate forest development through time based on historical natural disturbance rates, succession rules defining transition of stands from one forest type and/or age class to another, and yield curves. The model accounts for detailed silvicultural rules and prescriptions, management objectives, and environmental constraints to simulate a scenario that maximizes timber value available for harvesting.

Current and future carbon stocks in forests and HWP were estimated using FORCARB-ON2 (Chen et al. 2010, 2018a), the second version of the large-scale forest carbon budget model FORCARB-ON developed from the U.S. model FORCARB2 (Heath et al. 2010). FORCARB-ON2 can be used to estimate forest carbon stocks in six pools: live and standing dead trees (above- and belowground), down dead wood (i.e., large [>76 mm diameter] logs, branches 


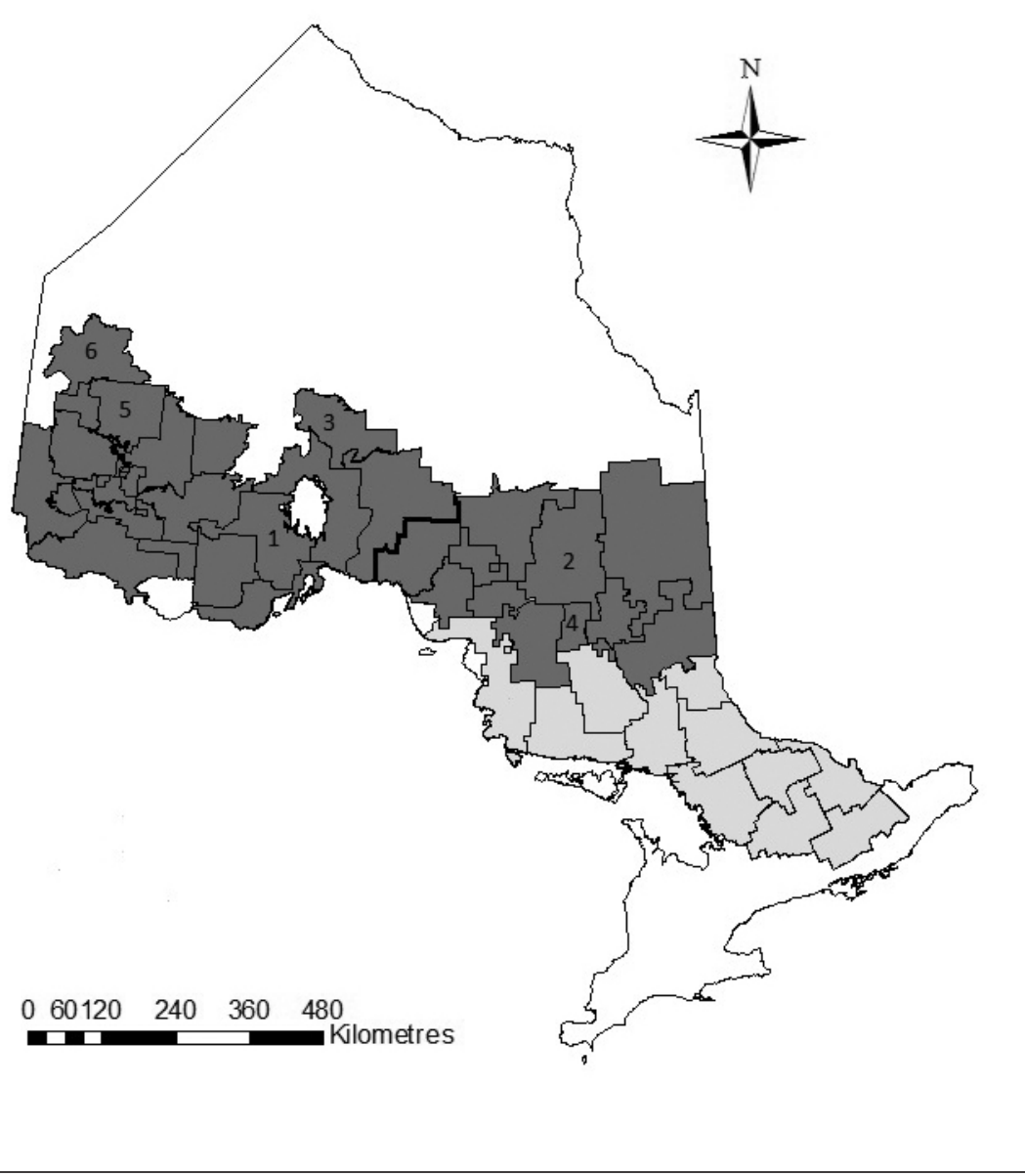

Fig. 1. Ontario forest management units; those shaded dark grey were included in the analysis. Thin black lines indicate unit boundaries; thick black line indicates the boundary between northwestern and northeastern region. Individual forest management units mentioned in the text: 1 - Black Spruce Forest; 2 - Gordon Cosens Forest; 3 - Ogoki Forest; 4 - Pineland Forest; 5 - Trout Lake Forest; 6 - Whitefeather Forest. methane emissions from wood/HWP decomposition, emissions reduced by using wood to substitute for fossil fuels, and emissions reduced by using HWP to replace non-wood materials in construction. The harvested wood is divided amongst four HWP categories based on past production estimates of fractions of lumber, structural panels (plywood and oriented strand board), non-structural panels (medium density fibreboard and particleboard), and pulp and paper (includes pulp, paper, and paper products). Carbon stocks in HWP and emissions from product decomposition are simulated for a given forest development scenario using a decay model and HWP category-specific retention parameters. More detail about the analysis of carbon stocks in HWP was documented by Chen et al. (2018b).

For each FMU, forest development was projected for 2020-2050 using SFMM based on model settings (disturbance rates, succession rules, yield curves, etc.) from the scenario that formed the basis for the most recent FMP. Forest inventory was updated to 2020 using actual harvest volumes (from the date of the preceding FMP to 2019) obtained from annual reports submitted by forest companies managing the FMUs. Future annual harvest volumes were assumed to stay constant during the 2020-2050 simulation period. For a given model scenario, carbon stocks predicted using FORCARB-ON2 were averaged over the simulation period.

To estimate relationships between carbon stocks and harvest volume, we and stumps), understory vegetation, forest floor (dead organic matter above the mineral soil horizon, including small [ $<76 \mathrm{~mm}$ diameter] branches and logs, litter, and humus), and soil. Estimates of carbon stocks are derived using relationships between net stand merchantable volume (live and standing dead trees) relationships with live tree biomass (down dead wood), stand age (forest floor and understory vegetation), forest region and type (soil). Unlike the first version of the model, FORCARB-ON, in FORCARB-ON2 carbon stocks in dead organic matter pools (standing dead trees, down wood, forest floor, and soil) are simulated using the processes of transition among various pools and decomposition of the pool content from the previous simulation step. Detailed descriptions of methods and parameter values used in FORCARB-ON2 are provided by Chen et al. (2010, 2018a).

FORCARB-ON2 also includes a module for estimating carbon stocks in HWP when simulated forests are harvested (Chen et al. 2018b). The model includes six HWP life-cycle components: carbon stocks of HWP in use, carbon stocks of wood/HWP in landfills, HWP production emissions, landfill generated various SFMM scenarios, each with a constant annual harvest volume. Environmental constraints to meet targets for forest age structure, species composition, or wildlife habitat, etc., were not included in the simulations. For each scenario, three carbon quantities were calculated by averaging the following values over 2020-2050: (a) forest ecosystem carbon stocks (sum of all live and dead organic matter pools), $\mathrm{C}_{\mathrm{for}}$; (b) sum of carbon stocks in forest ecosystem and harvested wood products (HWP) minus emissions associated with production and decomposition of HWP, $\mathrm{C}_{\text {for+HWP }}$; (c) net greenhouse gas (GHG) effects of harvest estimated in (b) combined with avoided emissions due to substitution of non-wood materials with HWP, $\mathrm{C}_{\text {net }}$. Emission components of $\mathrm{C}_{\text {for }+\mathrm{HWP}}$ and $\mathrm{C}_{\text {net }}$ were converted from carbon dioxide equivalent $\left(\mathrm{CO}_{2} \mathrm{eq}\right)$ to carbon; landfill methane emissions were converted to $\mathrm{CO}_{2}$ eq by considering their global warming potential (Chen et al. 2018b).

Preliminary model simulations for a randomly selected subset of six FMUs indicated a highly linear relationship between average carbon quantities during 2020-2050 ( $\mathrm{C}_{\mathrm{for}}$, $\mathrm{C}_{\text {for+HWP }}$, and $\mathrm{C}_{\text {net }}$ ) and harvest volume. In each FMU, the 
three carbon quantities were simulated for 11 equally spaced annual harvest volumes, ranging from zero (no harvest) to $2 \%$ of the FMU's total merchantable volume at the beginning of the simulation period. The lowest $\mathrm{R}^{2}$ among six FMUs for forest ecosystem carbon stocks, $\mathrm{C}_{\text {for }}$, regressed on harvest volume was 0.996; the standard error of estimate for $\mathrm{C}_{\text {for }}$ ranged from 0.042 to $0.271 \mathrm{MtC}$ (million tonnes of carbon) or, expressed on a relative scale, from 0.09 to $0.21 \%$ of the mean value of $\mathrm{C}_{\text {for }}$. Results were similar for $\mathrm{C}_{\text {for+HWP }}$, and $\mathrm{C}_{\text {net }}$ : for $\mathrm{C}_{\text {for }+\mathrm{HWP}}$, the minimum $\mathrm{R}^{2}$ among the six FMUs was 0.995 and the standard error of estimate ranged from 0.042 to $0.271 \mathrm{MtC}$ (from 0.8 to $0.21 \%$ of the mean $\mathrm{C}_{\text {for }+\mathrm{HWP}}$ ); for $\mathrm{C}_{\text {net' }}$ ' the minimum $\mathrm{R}^{2}$ was 0.991 and the range of standard errors of estimate was $0.42-0.27 \mathrm{MtC}(0.09-0.20 \%$ of the mean $\mathrm{C}_{\text {net }}$ ). Figure 2 shows an example of simulated values of $\mathrm{C}_{\text {for }}$, $\mathrm{C}_{\text {for+HWP }}$, and $\mathrm{C}_{\text {net }}$ and fitted regression lines for one of the six FMUs (Trout Lake Forest).

Based on these preliminary findings and to reduce the number of model simulations, for each of the 29 FMUs we used five equally spaced annual harvesting levels ranging from zero to $2 \%$ of the total merchantable volume present in a given FMU in 2020. The upper limit (2\%) was selected to reflect a realistic range of harvesting levels considered in the FMPs; in all but one FMU the maximum planned harvesting level was below $2 \%$ (the only exception was Crossroute Forest with a harvesting level of 2.28\%). Average carbon stocks during 2020-2050 corresponding to the five harvesting levels were used to estimate the coefficients of linear regression with annual harvest volume as the lone predictor; five points were used to ensure that the relationship for a given FMU did not deviate from linear.

Using the relationships developed, $\mathrm{C}_{\text {for }}, \mathrm{C}_{\text {for }+\mathrm{HWP}}$, and $\mathrm{C}_{\text {net }}$ were estimated for future harvest levels equal to average historical harvest rate for 1995-2014 for a given FMU. Historical annual harvest volumes for 1990 to 2018, averaged over five-year periods (1990-94, 1995-99, 2000-04, 2005-

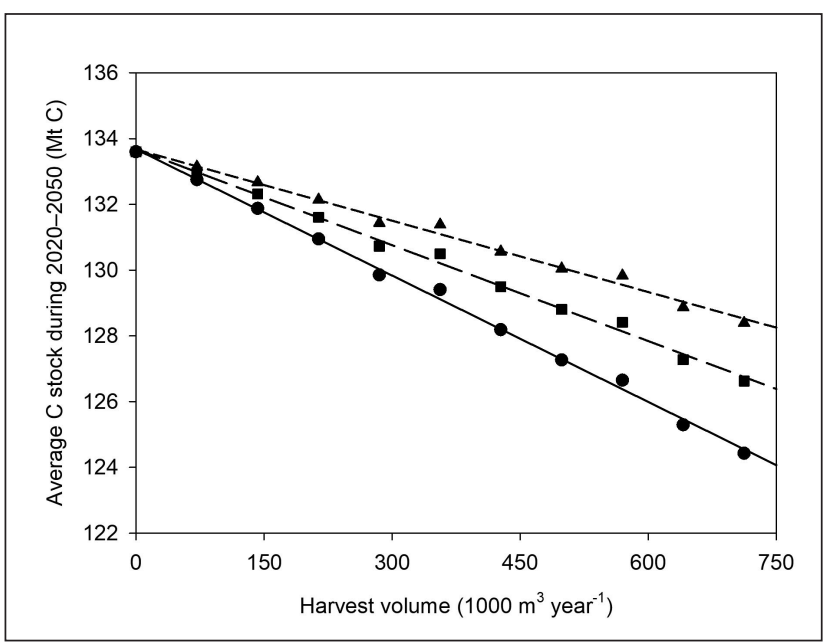

Fig. 2. Simulated values and fitted regression lines for three carbon quantities for the Trout Lake Forest management unit, Ontario: forest ecosystem carbon stocks (circles and solid line), sum of carbon stocks in forest ecosystem and harvested wood products minus associated emissions (squares and long-dashed line), and net greenhouse gas effects (triangles and short-dashed line).
09, 2010-14, 2015-18), were obtained from ARWoods (OMNRF 2020a). Since actual harvest volume fluctuated over time, the following procedure was applied to select a period over which the average historical harvest rate was estimated. First, for each five-year period, average actual harvest volume was summed for all 29 FMUs. The average annual harvest rate was then calculated for all combinations of consecutive five-year periods (i.e., 1990-94, 1990-99, 1990-2004, 1990-2009, 1990-2014, 1990-2018, 1995-99, 1995-2004, etc.). Calculated average annual harvesting rates were arranged in ascending order and the period 1995-2014, corresponding to the median value, was selected as the period for which average annual historical harvesting rate was estimated for each FMU.

"Natural equilibrium" forest ecosystem carbon stocks were estimated for a scenario in which forest growth in the absence of harvesting was simulated for 1000 years using the same parameters and model rules as in the FMP scenario, except for natural disturbance rates. Natural disturbance rates in the natural equilibrium scenarios equalled those in Ontario's pre-suppression era, i.e., before effective forest fire protection was available; estimates of pre-suppression disturbance rates are included in the FMP for each FMU. The relationships between carbon stocks and harvest volumes were used to estimate the harvesting rate that would result in the three carbon quantities, $\mathrm{C}_{\text {for }}, \mathrm{C}_{\text {for+HWP }}$, and $\mathrm{C}_{\text {net, }}$, equal to the natural equilibrium forest ecosystem carbon stocks at the end of a 1000-year-long simulation.

\section{Results}

Total forest ecosystem carbon stocks for the 29 FMUs combined in 2020 were estimated to be 3635 Mt C (million tonnes of carbon in trees, soil, and dead organic matter); forest ecosystem carbon densities (carbon stocks per unit of forested area) for individual FMUs ranged from 140.4 to $178.8 \mathrm{t} \mathrm{C} \mathrm{ha}^{-1}$ (tonnes of carbon per hectare). Annual harvesting rates in the 29 FMUs during 1995-2014 averaged 14.44 million $\mathrm{m}^{3}$ year ${ }^{-1}$, ranging from 0.12 to 1.15 million $\mathrm{m}^{3}$ year${ }^{1}$ for individual FMUs, which is from 0.25 to $1.65 \%$ of the total merchantable volume present in 2020. The historical harvesting range for individual FMUs does not include one of the 29 FMUs (Whitefeather Forest), in which commercial harvesting did not occur before 2015. Forest state statistics and estimated carbon stocks for individual FMUs are presented in Table A1 (see Appendix).

Relationships between harvest volume and average carbon stocks during 2020-2050 for all FMUs combined were estimated as:

$$
\begin{aligned}
& \mathrm{C}_{\text {for }}=3757.0-9.96^{\bullet} \mathrm{V}_{\text {harv }} \\
& \mathrm{C}_{\text {for }+\mathrm{HWP}}=3757.0-7.78^{\bullet} \mathrm{V}_{\text {harv }} \\
& \mathrm{C}_{\text {net }}=3757.0-6.13^{\bullet} \mathrm{V}_{\text {harv }}
\end{aligned}
$$

where $\mathrm{C}_{\text {for }}, \mathrm{C}_{\text {for }+\mathrm{HWP}}$, and $\mathrm{C}_{\text {net }}$ are carbon stocks in $\mathrm{Mt} \mathrm{C}$ as defined in the previous section, and $\mathrm{V}_{\text {harv }}$ is average annual merchantable volume (million $\mathrm{m}^{3}$ year $\left.{ }^{-1}\right)$ harvested during 2020-2050. Relationships (1)-(3) for all FMUs combined and two representative individual FMUs are shown in Fig. 3. All relationships were inspected for deviations from the lin- 
ear pattern. Standard errors of estimate for the relationships (1)-(3) for all FMUs combined were equal to 0.025, 0.022, and $0.020 \%$ of the mean value of the respective quantity. Standard errors of estimate for individual FMUs for relationships (1)-(3) ranged from $0.016-0.297 \%, 0.016-0.294 \%$, and $0.016-0.291 \%$ of the mean values of the respective quantities.

Pre-suppression natural disturbance cycles for individual FMUs ranged from 63 to 303 years, with the area-weighted average for all FMUs equal to 122 years; the area-weighted average pre-suppression natural disturbance fire cycle for the 11 northeastern FMUs was 148 years, and for the 18 northwestern FMUs it was 103 years. Relationships of the types (1)-(3) were used to estimate average annual harvest volumes during 2020-2050 that would have resulted in $\mathrm{C}_{\text {for }}, \mathrm{C}_{\text {for }+\mathrm{HWP}}$ and $\mathrm{C}_{\text {net }}$ equal to natural equilibrium carbon stocks. For 23 FMUs, harvesting from 2020 to 2050 at recent historical levels would result in more carbon in $\mathrm{C}_{\text {for }}, \mathrm{C}_{\text {for }+\mathrm{HWP}}$, and $\mathrm{C}_{\text {net }}$ compared to what would exist in those same forests in a natural equilibrium condition (same pattern as in Fig. 3a). For five FMUs, natural equilibrium carbon stocks were higher relative to those when the FMUs harvested at the historical rates (same pattern as in Fig. 3b showing relationships for Pineland FMU). For one FMU (Gordon Cosens Forest), natural equilibrium carbon stocks were higher than forest ecosystem carbon stocks corresponding to no harvesting during 2020-2050 (Fig 3c).

\section{Discussion}

Our study results show that increased harvesting lowers forest carbon stocks and increases net atmospheric greenhouse gas emissions from 2020 to 2050. This result was expected because of the relatively short simulation period: forests regrowing on harvested sites are too young to sequester enough carbon to offset losses from trees removed during harvesting

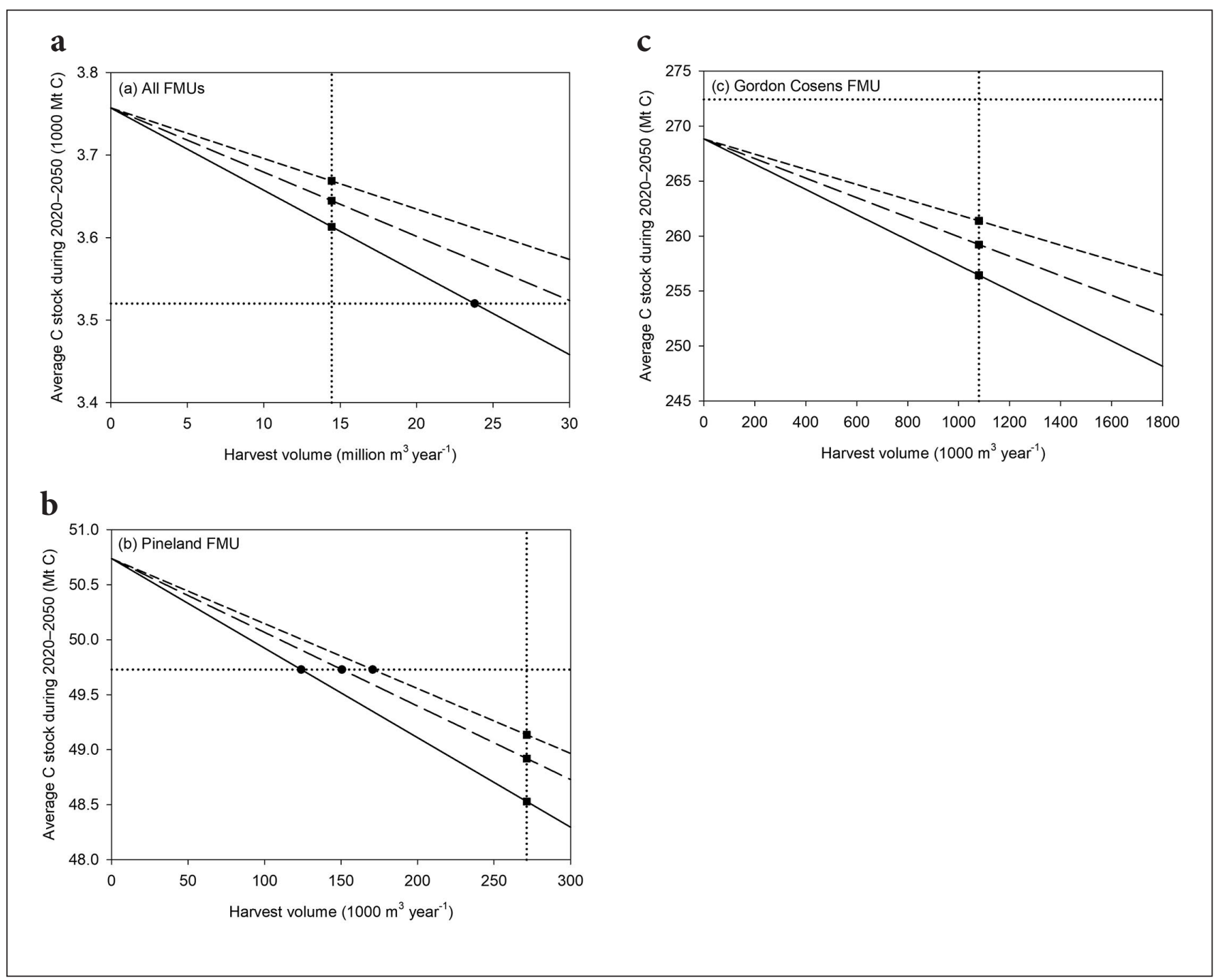

Fig. 3. Relationship between harvest volume and forest ecosystem carbon stocks (solid line), sum of carbon stocks in forest ecosystem and harvested wood products minus associated emissions (long-dashed line), and net greenhouse gas effects (short-dashed line) for (a) all 29 forest management units (FMU) combined, (b) Pineland Forest, and (c) Gordon Cosens Forest in Ontario. For a given harvesting level, all three carbon quantities are averaged for 2020-2050. Vertical dotted lines correspond to the average harvesting level from 1995-2014. Horizontal dotted lines correspond to forest ecosystem carbon stocks in an equilibrium state with pre-suppression natural disturbance rate. 
and from dead organic matter decomposing after harvesting. Declining carbon stocks with increased harvesting is consistent with previous findings on the effects of harvesting studied at regional and broader scales (e.g., Depro et al. 2008; Liu and Han 2009; Bradford et al. 2013; Ter-Mikaelian et al. 2013). Less expected was the strong linear dependence of all carbon quantities $\left(\mathrm{C}_{\text {for }}, \mathrm{C}_{\text {for }+\mathrm{HWP}}\right.$, and $\left.\mathrm{C}_{\text {net }}\right)$ on harvesting level (Figs. 2 and 3). Linearity likely reflects the relatively short prediction period (30 years), which was insufficient for non-linear processes, such as stand growth and changes in tree composition caused by successional transitions, to noticeably affect the relationship among carbon stocks, avoided emissions, and harvesting level.

A contributing factor might have been that we maintained the ratio of softwood to hardwood volume harvested in each FMU. The ratio was obtained from planned harvest volumes in the most recent FMPs. Simulations using longer time periods (up to 50 years) continued to indicate a linear dependence of carbon stocks on harvest volume, albeit with coefficient values different from those in (1)-(3). However, we restricted projections to 30 years to avoid more uncertain longer-term forest growth projections. Given changes in temperature and precipitation projected for Ontario (Colombo et al. 2015), it is unlikely that forest growth will remain at historical levels, and projecting what future forest growth might be was beyond the scope of this study.

Dependence of the three carbon quantities on harvesting volume was also linear when these quantities were estimated for a particular future time instead of averaging them over the entire prediction period. For example, Fig. A1 (see Appendix) shows relationships between the three carbon quantities estimated for 2050 and harvesting volume for all FMUs combined, as well as for two FMUs presented in Fig. 3 (Pineland Forest and Gordon Cosens Forest). Aside from the linearity of relationships, Fig. Alc illustrates the reason for averaging carbon quantities over 2020-2050: unlike Fig. 3c, the three quantities in 2050 for low harvesting levels are higher than carbon stocks in an equilibrium state with the pre-suppression natural disturbance rate. Thus, showing the three carbon quantities only in 2050 would obscure the fact that in this particular FMU, even for the zero-harvest scenario, average forest carbon stocks during 2020-2050 are projected to be lower than those in an equilibrium state with presuppression rate of natural disturbance.

The relationship between both forest carbon stocks and the net emissions of carbon to the atmosphere with harvest volume varies among FMUs. The slope of the linear relationships is affected by the growth and disturbance rates that are specific to each FMU (Ter-Mikaelian et al. 2014). In comparison, carbon sequestration by forests regenerating in harvested areas are not a major factor because of the relatively short prediction period. The most important factor affecting the relationship between forest carbon/net emissions of carbon with harvest volumes is the legacy of previous management and disturbance history determining starting forest condition (i.e., species composition and age structure), which in turn affects the future carbon sequestration rate (Kurz et al. 2013; Sharma et al. 2013). The effect of starting forest condition is also pronounced in the pattern of forest ecosystem carbon stock change during 2020-2050: for a relatively young FMU (area weighted age of forest 54 years), all simulated harvest scenarios resulted in either increasing or stable carbon stocks (Fig. 4a), while in an older FMU (area weighted age of forest 104 years), carbon stocks decreased (Fig. 4b), even in the no harvesting scenario (not shown). These results are consistent with previous long-term simulation of FMU-scale forest carbon stocks (Ter-Mikaelian et al. 2013).

The slope of relationships between the sum of carbon stocks in forest ecosystem and HWP, $\mathrm{C}_{\text {for }+\mathrm{HWP}}$, and harvest volume, as well as between net GHG effects, $C_{\text {net, }}$, and harvest volume, also depend on the types of HWP produced and the types of end uses. In all projections, we used the same historical production fractions of harvested wood into finished products as estimated by Chen $\mathrm{et}$ al. (2018a). Meanwhile, carbon retention time and end-of-use emissions are HWP category specific and so are substitution effects of replacing non- a

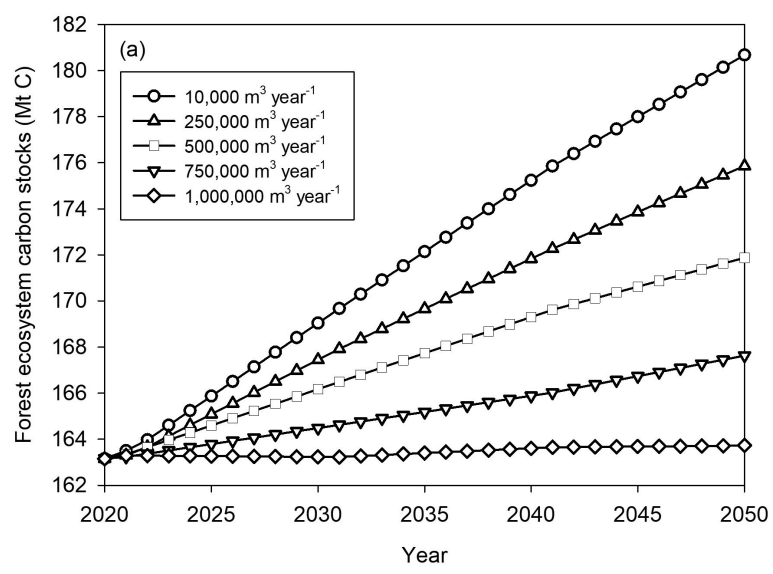

b

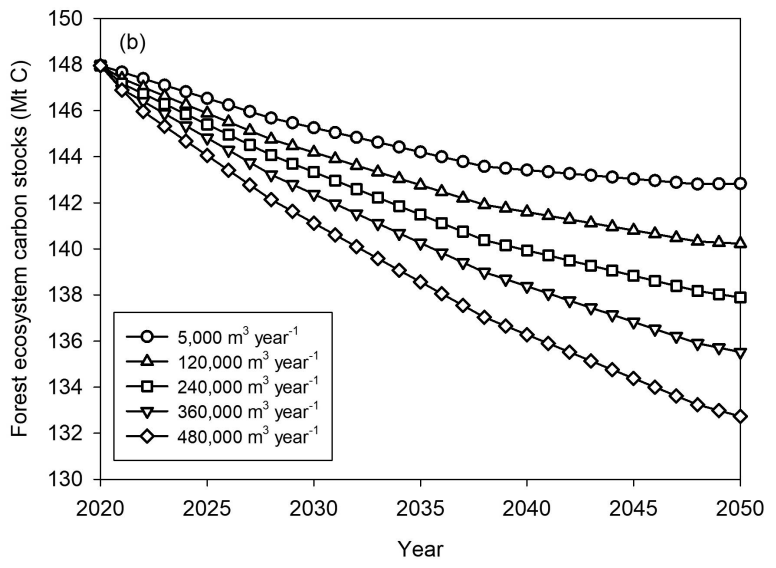

Fig. 4. Projected forest ecosystem carbon stocks for five harvesting levels during 20२०-205० for the (a) Black Spruce Forest (average area weighted age 54) and (b) Ogoki Forest (average area weighted age 104) management units in Ontario. 
wood materials that are estimated only for the fraction of harvested wood converted into solid HWPs used in construction. As demonstrated by Smyth et al. (2014) and Chen et al. (2018b), increasing the fraction of wood in solid HWP used in long-lived end uses reduces the timeframe to achieve net emissions reductions by harvesting forests. Future changes to the utilization of harvested wood among HWP categories depend on socioeconomic factors, such as population, economic growth, education, urbanisation, and the rate of technological development. These factors are reflected in the socalled shared socioeconomic pathways (SSPs), which describe different ways in how society might evolve. Different scenarios consider the overall demand for HWP as well as country-specific distribution of fibre from future harvests among HWP categories. For example, in simulations by Johnston and Radeloff (2019), the ratio of wood panels to construction lumber produced in Canada by 2065 may vary from 0.32 to 0.59 depending on SSP scenario. Predictions of future HWP demand are outside of the scope of this study, however, it is important to note that the allocation of future harvest volumes among HWP categories will affect the slope of relationships (2) and (3).

We used pre-suppression natural disturbance cycle forest ecosystem carbon stocks as a benchmark to compare the effects of harvesting rates. Our results show that in most of Ontario's 29 managed Crown boreal forest units individually as well as in all units combined, forests currently contain more carbon than would be stored in the natural disturbance benchmark and would continue to do so even with substantial increases in harvesting. The principle reason for this is that Ontario's forest fire suppression efforts have reduced the area burned far below what would have burned in unmanaged forests (Bergeron 2004; Colombo et al. 2012). Thus, in the short term (30 years), although harvesting reduces carbon below levels that would result with no harvesting, it does so at the expense of other ecological values. As demonstrated by Colombo et al. (2012), reducing harvesting and continuing intensive fire suppression produces an aging forest with fewer younger age classes. Emulating natural forest age class composition in areas with shorter natural disturbance return intervals requires removal of older forest to maintain younger age classes. Figure 3 a shows the range of average annual harvest volumes (from 0 to 23.8 million $\mathrm{m}^{3}$ year ${ }^{-1}$ ) that would result in average forest ecosystem carbon stocks higher than those for a pre-suppression natural disturbance cycle (intersection of solid and horizontal dotted lines in Fig. 3a). If the sum of carbon stocks in forest and HWP minus associated emissions (long-dashed line in Fig. 3a) or net GHG effects (short-dashed line in Fig. 3a) were compared with carbon stocks for equilibrium forest state for pre-suppression natural disturbance cycles, the range of average annual harvest volumes would increase to from 0 to 30.5 million $\mathrm{m}^{3}$ year $^{-1}$ and from 0 to 38.7 million $\mathrm{m}^{3}$ year $^{-1}$, respectively.

Of the three carbon quantities considered in this study, we find the most informative to be $\mathrm{C}_{\text {for }+\mathrm{HWP}}$ since it accounts for both carbon stocks in forest ecosystems and HPW in use and landfills, and the associated life cycle inventory emissions. Although avoided emissions included in $\mathrm{C}_{\text {net }}$ are also a useful indicator of the overall GHG effects of forest harvesting (Kurz et al. 2016), uncertainty about the size of substitution effects is higher, especially for harvest volumes higher than historical levels. The latter uncertainty comes from two sources. The first stems from the so-called rebound effect, in which a gap exists between the decreased use of resources expected from increased "eco-efficiency" and their actual utilization (Holm and Englund 2009). In the context of HWP, the rebound effect means new opportunities for utilization of displaced non-wood materials that result in lower than expected emissions avoided due to substitution. Examples of such rebound effects for forest bioenergy are discussed by Agostini et al. (2013).

The second source of uncertainty is related to the future use of HWP in construction. Substitution effects are estimated in FORCARB-ON2 by applying a weighted average displacement factor for all HWP used to replace alternative (non-wood) materials in construction (Chen et al. 2018b). In addition to the above-discussed global factors affecting future production of various categories of HWP, their use in construction depends also on domestic factors. For example, Gosselin et al. (2015) used an analysis of various Canadian and international construction projects to identify the main motivations and barriers to the use of wood for structural purposes. The motivations are linked to factors such as the use of a sustainable resource that helps to mitigate climate change, rapidity of erection, lower material and construction costs, favorable publicity, and the lightness of wooden structures as a factor affecting soil bearing capacity of buildings. Meanwhile, barriers to using wood include building codes, lack of familiarity of wood use in tall structures by engineers and architects, concerns about material durability and lack of supply of cross-laminated timber or other advanced wood building material. The ability of wood producers to address barriers to and promote motivations for using wood building materials, along with global socioeconomic factors will ultimately determine whether the use of wood in construction increases or decreases, and this makes predicting the net GHG effects of harvesting less certain than the other two carbon quantities estimated in this study.

For many boreal forests in Canada, including Ontario, Bergeron (2004) observed shorter natural disturbance cycles now than historically and suggested that this reduction creates opportunity for emulating natural disturbance, which is a main principle guiding Ontario's forest management (Statutes of Ontario 1994). Based on our results, higher harvesting rates could emulate the area of natural disturbance, resulting in forest ecosystem carbon stocks or net GHG effects of harvesting that are also more aligned with natural equilibrium forest carbon stocks. We did not evaluate whether managing for carbon stock levels in this way is achievable in practice since other environmental constraints (e.g., forest areas for wildlife habitat) were not included in model runs. Colombo et al. (2012) demonstrated that both high harvest volumes and the absence of harvesting can lead to age structures that differ substantially from those typical of natural conditions. Thus, meeting all sustainability requirements for forest management may impose some restrictions to the harvest volume changes that could be implemented. In fact, FMPs are developed based on maximizing merchantable volume that can be harvested at each simulation step, and resulting estimates of future harvest volumes usually fluctuate over time; in the absence of reasons that would justify 
variable harvesting levels (such as predictions of future market demand), we chose to keep harvest volume constant in each scenario throughout the simulation.

Results of the analysis for Ontario's boreal FMUs suggest that decreased harvesting is a potential strategy for storing more forest ecosystem carbon for at least the next 30 years. This outcome, however, is contingent on being able to protect these forests from natural disturbance. As stated by Sharma et al. (2013), in boreal forests, conservation may or may not contribute to climate change mitigation because of the risk of carbon losses from natural disturbance events.

As well, carbon storage is only one indicator of the forest's ecological state, with others including the above-mentioned age structure, species composition, and ability to provide wildlife habitat (OMNRF 2014). Reducing harvesting levels may adversely affect other benefits from the forestry sector, such as decreased use of fossil fuels and substitution of GHG emission-costly materials (such as concrete). As pointed out by Vance (2018), "there is strong evidence to support the long-term carbon benefits of actively managed forests compared to their unmanaged counterparts, however, when harvested biomass is efficiently used for wood products and to replace fossil fuels." Another potentially negative consequence of reduced harvesting is the so-called leakage effect when harvesting rates are reduced in one area but increased elsewhere (Lemprière et al. 2013). Leakage may cause the unintended effect of reducing rather than increasing mitigation if production emissions are substantially higher in other locations or in other industries (Leskinen et al. 2018).

From a more general viewpoint, the benefits of forest carbon storage must be assessed in the context of valuation of ecosystem services provided by forests. Ecosystem services refer to the benefits that people derive from functioning ecosystems, and are defined as the ecological characteristics, functions, or processes that directly or indirectly contribute to human well-being (Costanza et al. 2017). Classification of ecosystem services, as well as their estimated value for various biomes, was presented in a seminal paper by Costanza et al. (1997). Since then, the number of research papers on valuation of ecological services has increased exponentially, with fibre supply and carbon storage amongst the key services considered (Acharya et al. 2019). For example, Schwaiger et al. (2019) assessed the effects of three forest management scenarios on four ecosystem services (groundwater recharge, carbon sequestration, wood production, structural diversity of forest stands) in two different forest landscapes in Germany. Sing et al. (2018) reviewed the effects of forest management on seven ecosystem services provided by northern European temperate forests (timber/biomass production, carbon storage, biodiversity, health and recreation, water supply and quality and flood protection). Roberge et al. (2016) used Fennoscandian forestry as a case to review the effects of modifying harvest rotation lengths relative to current practice on a range of provisioning, regulating, cultural, and supporting ecosystem services. Each study of this type helps identify synergies and trade-offs among ecosystem services resulting from different forest management approaches.

The effects of harvesting level on forest condition (other than carbon stocks) and ecosystem services provided by forests were beyond the scope of this study. However, we submit that it would be erroneous to consider the effects of harvest volumes on carbon stocks in isolation from other ecosys- tem services. Having said this, the likely outcome of assessing a suite of environmental services is that the expected benefits for one service will necessarily be accompanied by varied and often contrasting effects on other services (Roberge et al. 2016). This challenge emphasizes the need for improved communication and discussion amongst stakeholders with differing views on the relative importance of individual ecosystem services. As pointed out by Costanza et al. (2017), "even without any subsequent valuation, the very process of listing all the services derived from an ecosystem can help ensure their recognition in public policy" and informs the public and decision-makers of the relative advantages and disadvantages of various options.

\section{Acknowledgements}

We thank Lisa Buse with the Ontario Ministry of Natural Resources and Forestry for editing an earlier version of this manuscript. We also thank an anonymous reviewer and the Associate Editor, whose thoughtful comments helped us improve the manuscript.

\section{References}

Acharya, R.P., T. Maraseni and G. Cockfield. 2019. Global trend of forest ecosystem services valuation-An analysis of publications. Ecosyst. Serv. 39: 100979.

Agostini, A., J. Giuntoli and A. Boulamanti. 2013. Carbon accounting of forest bioenergy. Joint Research Centre of the European Commission, Ispra. Available at https://www.energy.eu/publications/Carbon-accounting-of-forest-bioenergy.pdf [accessed 25 May 2020].

Bergeron, Y. 2004. Is regulated even-aged management the right strategy for the Canadian boreal forest? For. Chron. 80(4): 458-462. Böttcher, H. and M. Lindner. 2010. Managing forest plantations for carbon sequestration today and in the future. In: Ecosystem goods and services from plantation forests (pp. 59-92). Routledge. Bradford, J.B. 2011. Potential influence of forest management on regional carbon stocks: An assessment of alternative scenarios in the northern Lake States, USA. Forest Science 57(6): 479-488.

Bradford, J.B., N.R. Jensen, G.M. Domke and A.W. D'Amato. 2013. Potential increases in natural disturbance rates could offset forest management impacts on ecosystem carbon stocks. Forest Ecol. Manag. 308: 178-187.

Chen, J., S.J. Colombo, M.T. Ter-Mikaelian, and L.S. Heath. 2010. Carbon budget of Ontario's managed forests and harvested wood products, 2001-2100. Forest Ecol. Manag. 259: 1385-1398.

Chen, J., M.T. Ter-Mikaelian, P.Q. Ng and S.J. Colombo. 2018a. Ontario's managed forests and harvested wood products contribute to greenhouse gas mitigation from 2020 to 2100 . For. Chron. 43(3): 269-282.

Chen, J., M.T. Ter-Mikaelian, H. Yang and S.J. Colombo. $2018 b$. Assessing the greenhouse gas effects of harvested wood products manufactured from managed forests in Canada. Forestry: An Intern. J. Forest Res. 91(2): 193-205.

Colombo, S.J., J. Chen, M.T. Ter-Mikaelian, J. McKechnie, P.C. Elkie, H.L. MacLean and L.S. Heath. 2012. Forest protection and forest harvest as strategies for ecological sustainability and climate change mitigation. Forest Ecol. Manag. 281: 140-151.

Colombo, S.J., P.A. Gray, P.J. Partington and D. Pearson. 2015. Beyond 450 parts per million: Climate change hazards in a $4{ }^{\circ} \mathrm{C}$ warmer world and how Ontario can help avoid them. Ontario Centre for Climate Impacts and Adaptation Resources, Sudbury, ON/Ontario Ministry of Natural Resources and Forestry, Peterborough, ON.

Costanza, R., R. d'Arge, R. De Groot, S. Farber, M. Grasso, B. Hannon, K. Limburg, S. Naeem, R.V. O'Neill, J. Paruelo and 
R.G. Raskin. 1997. The value of the world's ecosystem services and natural capital. Nature 387 (6630): 253-260.

Costanza, R., R. De Groot, L. Braat, I. Kubiszewski, L. Fioramonti, P. Sutton, S. Farber and M. Grasso. 2017. Twenty years of ecosystem services: How far have we come and how far do we still need to go? Ecosystem Services 28: 1-16.

Depro, B.M., B.C. Murray, R.J. Alig and A. Shanks. 2008. Public land, timber harvests, and climate mitigation: Quantifying carbon sequestration potential on US public timberlands. Forest Ecol. Manag. 255 (3-4): 1122-1134.

Gosselin, A, N.A. Lehoux, Y. Cimon and P.I. Blanchet. 2015. Main motivations and barriers for using wood as a structural building material-A case study. In: 11th International Industrial Engineering Conference 2015 Oct 26 (pp. 26-28). Available at http:// www.simagi.polymtl.ca/congresgi/cigi2015/Articles/CIGI_2015_ submission_116.pdf [accessed 19 January 2021].

Harmon, M.E., A. Moreno and J.B. Domingo. 2009. Effects of partial harvest on the carbon stores in Douglas-fir/western hemlock forests: A simulation study. Ecosyst. 12(5): 777-791.

Heath, L.S., M.C. Nichols, J.E. Smith and J.R. Mills. 2010. FORCARB2: an updated version of the US Forest Carbon Budget Model. Newtown Square, PA: US Department of Agriculture, Forest Service, Northern Research Station.

Holm, S.O. and G. Englund. 2009. Increased ecoefficiency and gross rebound effect: Evidence from USA and six European countries 1960-2002. Ecol. Econ. 68(3): 879-887.

Johnston, C.M. and V.C. Radeloff. 2019. Global mitigation potential of carbon stored in harvested wood products. Proceedings of the National Academy of Sciences 116(29): 14526-14531.

Kaipainen, T., J. Liski, A. Pussinen and T. Karjalainen. 2004. Managing carbon sinks by changing rotation length in European forests. Environ. Sci. Policy 7(3): 205-219.

Kilpeläinen, A., P. Torssonen, H. Strandman, S. Kellomäki, A. Asikainen and H. Peltola. 2016. Net climate impacts of forest biomass production and utilization in managed boreal forests. GCB Bioenergy 8(2): 307-316.

Kloss, D. 2002. Strategic Forest Management Model Version 2.0 user guide. Ontario Ministry Natural Resources, Forest Management Branch, Forest Management Planning Section, Sault Ste. Marie, Ontario, Canada.

Kurz, W.A., C. Smyth and T. Lemprière. 2016. Climate change mitigation through forest sector activities: Principles, potential and priorities 1. Unasylva 67(246): 61.

Kurz, W.A., C.H. Shaw, C. Boisvenue, G. Stinson, J. Metsaranta, D. Leckie, A. Dyk, C. Smyth and E.T. Neilson. 2013. Carbon in Canada's boreal forest-a synthesis. Environ. Rev. 21(4): 260-292.

Lemprière, T.C., W.A. Kurz, E.H. Hogg, C. Schmoll, G.J. Rampley, D. Yemshanov, D.W. McKenney, R. Gilsenan, A. Beatch, D. Blain and J.S. Bhatti. 2013. Canadian boreal forests and climate change mitigation. Environ. Rev. 21(4): 293-321.

Leskinen, P., G. Cardellini, S. González-García, E. Hurmekoski, R. Sathre, J. Seppälä, C. Smyth, T. Stern and P.J. Verkerk. 2018. Substitution effects of wood-based products in climate change mitigation. From Science to Policy 7. European Forest Institute. https://doi.org/10.36333/fs07

Liu, G. and S. Han. 2009. Long-term forest management and timely transfer of carbon into wood products help reduce atmospheric carbon. Ecol. Model. 220(13-14): 1719-1723.

Nunery, J.S. and W.S. Keeton. 2010. Forest carbon storage in the northeastern United States: net effects of harvesting frequency, postharvest retention, and wood products. Forest Ecol. Manag. 259(8): 1363-1375.

OMNRF. 2014. [Ontario Ministry of Natural Resources and Forestry]. Forest Management Guide for Boreal Landscapes. Toronto, Queen's Printer for Ontario. 104 p. Available at https:// docs.ontario.ca/documents/4543/boreal-landscape-guide-march11-2014-final-s.pdf [accessed 25 May 2020].
OMNRF. 2016. [Ontario Ministry of Natural Resources and Forestry]. Ontario's Crown forests: Opportunities to enhance carbon storage? A discussion paper. Available at https://apps. mnr.gov.on.ca/public/files/er/mnrf-16-244-discussion-paper.pdf [accessed 25 May 2020].

OMNRF. 2020a. [Ontario Ministry of Natural Resources and Forestry]. Analysis of regional wood supply (ARWoodS). Available at https://data.ontario.ca/dataset/analysis-of-regional-wood-supply [accessed 25 May 2020].

OMNRF. 2020b. [Ontario Ministry of Natural Resources and Forestry]. Forest Management Plans Online. Available at https://nrip.mnr.gov.on.ca/s/fmp-online?language=en_US [accessed 19 January 2021].

Pan, Y., R.A. Birdsey, J. Fang, R. Houghton, P.E. Kauppi, W.A. Kurz, O.L. Phillips, A. Shvidenko, S.L. Lewis, J.G. Canadell and P. Ciais. 2011. A large and persistent carbon sink in the world's forests. Science 333(6045): 988-993.

Roberge, J.M., H. Laudon, C. Björkman, T. Ranius, C. Sandström, A. Felton, A. Sténs, A. Nordin, A. Granström, F. Widemo and J. Bergh 2016. Socio-ecological implications of modifying rotation lengths in forestry. Ambio 45(2): 109-123.

Schwaiger, F., W. Poschenrieder, P. Biber and H. Pretzsch. 2019. Ecosystem service trade-offs for adaptive forest management. Ecosyst. Serv. 39: 100993.

Sing, L., M.J. Metzger, J.S. Paterson and D. Ray. 2018. A review of the effects of forest management intensity on ecosystem services for northern European temperate forests with a focus on the UK. Forestry: Intern. J. Forest Res. 91(2): 151-164.

Sharma, T., W.A. Kurz, G. Stinson, M.G. Pellatt and Q. Li. 2013. A 100-year conservation experiment: Impacts on forest carbon stocks and fluxes. Forest Ecol. Manag. 310: 242-255.

Smith P., M. Bustamante, H. Ahammad, H. Clark, H. Dong, H. Elsiddig, H. Haberl, R. Harper, J. House, M. Jafari, O. Masera, C. Mbow, N.H. Ravindranath, C.W. Rice, C. Robledo Abad, A. Romanovskaya, F. Sperling and F. Tubiello. 2014. Agriculture, Forestry and Other Land Use (AFOLU). In: Climate Change 2014: Mitigation of Climate Change. Contribution of Working Group III to the Fifth Assessment Report of the Intergovernmental Panel on Climate Change [Edenhofer, O., R. Pichs-Madruga, Y. Sokona, E. Farahani, S. Kadner, K. Seyboth, A. Adler, I. Baum, S. Brunner, P. Eickemeier, B. Kriemann, J. Savolainen, S. Schlömer, C. von Stechow, T. Zwickel and J.C. Minx (Eds.)]. Cambridge University Press, Cambridge, United Kingdom and New York, NY, USA.

Smyth, C., G. Rampley, T.C. Lemprière, O. Schwab and W.A. Kurz. 2017. Estimating product and energy substitution benefits in national-scale mitigation analyses for Canada. GCB Bioenergy 9(6): 1071-1084.

Smyth, C.E., G. Stinson, E. Neilson, T.C. Lemprière, M. Hafer, G.J. Rampley and W.A. Kurz. 2014. Quantifying the biophysical climate change mitigation potential of Canada's forest sector. Biogeosciences 11(13): 3515.

Statutes of Ontario. 1994. Crown Forest Sustainability Act, revised. Available at https://www.ontario.ca/laws/statute/94c25 [accessed 25 May 2020].

Ter-Mikaelian, M.T., S.J. Colombo and J. Chen. 2013. Effects of harvesting on spatial and temporal diversity of carbon stocks in a boreal forest landscape. Ecol. Evol. 3(11): 3738-3750.

Ter-Mikaelian, M.T., S.J. Colombo and J. Chen. 2014. Effect of age and disturbance on decadal changes in carbon stocks in managed forest landscapes in central Canada. Mitig. Adapt. Strat. Gl. Change 19(7): 1063-1075.

Vance, E.D. 2018. Conclusions and caveats from studies of managed forest carbon budgets. Forest Ecol. Manag. 427: 350-354.

Watkins, L. 2011. The forest resources of Ontario 2011. Ontario Ministry of Natural Resources, Sault Ste. Marie Ontario, Forest Evaluation and Standards Section, Forests Branch. 307 p. Available at https://www.ontario.ca/document/forest-resources-ontario-2011 [accessed 25 May 2020]. 


\section{Appendix}

a

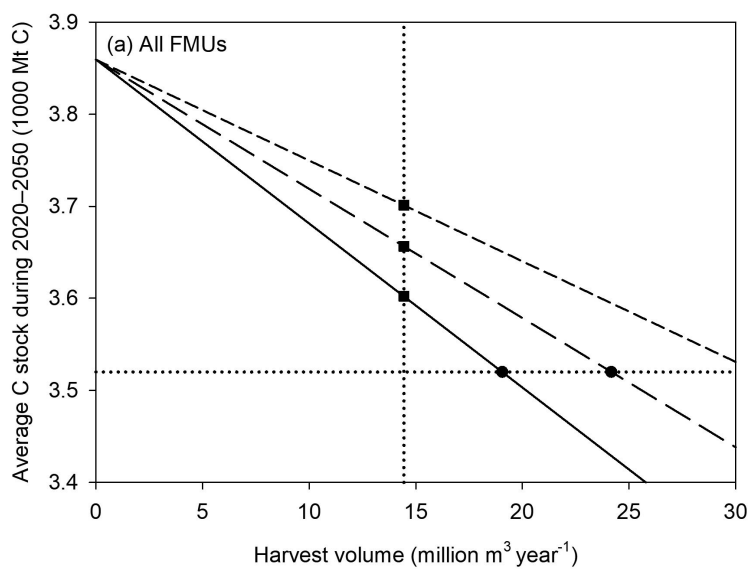

b

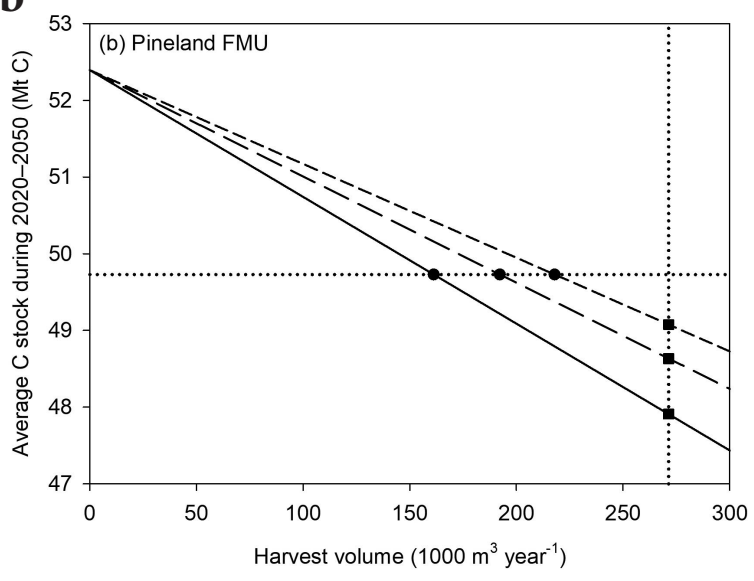

C

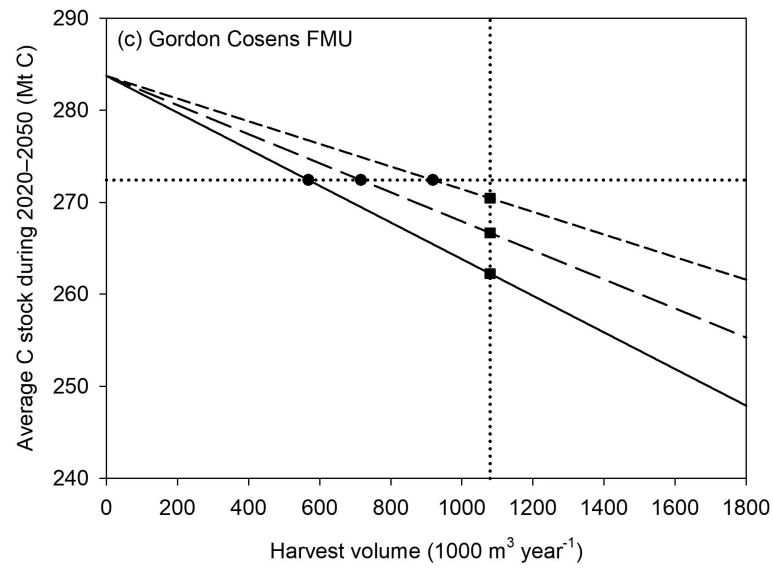

Fig. A1. Relationship between harvest volume and forest ecosystem carbon stocks (solid line), sum of carbon stocks in forest ecosystem and harvested wood products minus associated emissions (long-dashed line), and net greenhouse gas effects (short-dashed line) for (a) all 29 forest management units (FMU) combined, (b) Pineland Forest, and (c) Gordon Cosens Forest in Ontario. All three carbon quantities are estimated for 2050. Vertical dotted lines correspond to the average harvesting level from 1995-2014. Horizontal dotted lines correspond to forest ecosystem carbon stocks in an equilibrium state with pre-suppression natural disturbance rate. 
Table A1. Data on Forest Management Units (individually and combined) including: Region (NE - northeastern, NW - northwestern); Total forest area, total growing stock, and total forest ecosystem carbon stocks in 2020; Historical harvest volume estimated as average annual harvest during 1995-2014; Average forest ecosystem carbon stocks during 2020-2050 corresponding to natural historical harvest rate; Equilibrium forest ecosystem carbon stocks for natural pre-suppression disturbance rate; Historical harvest rate; Harvest rate corresponding to equilibrium forest ecosystem stocks for natural pre-suppression disturbance rate.

\begin{tabular}{|c|c|c|c|c|c|c|c|c|c|}
\hline \multirow[b]{2}{*}{ Region } & \multirow[b]{2}{*}{ Forest Management Unit } & \multicolumn{3}{|c|}{ Forest state in 2020} & \multirow[b]{2}{*}{$\begin{array}{c}\text { Historical } \\
\text { harvest } \\
\text { volume } \\
\left(10^{3}\right. \\
\left.\text { m }^{3} \text {-year }^{-1}\right)\end{array}$} & \multicolumn{2}{|c|}{$\begin{array}{l}\text { Forest ecosystem carbon } \\
\text { stocks }(\mathrm{Mt} \mathrm{C})\end{array}$} & \multicolumn{2}{|c|}{$\begin{array}{l}\text { Average annual harvest } \\
\text { rate (\% of total growing } \\
\text { tock in } 2020)\end{array}$} \\
\hline & & $\begin{array}{c}\text { Forest } \\
\text { area } \\
\left(10^{3} \mathrm{ha}\right)\end{array}$ & $\begin{array}{l}\text { Growing } \\
\text { stock } \\
\left(10^{6} \mathrm{~m}^{3}\right)\end{array}$ & $\begin{array}{l}\text { Ecosystem } \\
\text { carbon } \\
\text { stocks } \\
(\text { Mt C) }\end{array}$ & & $\begin{array}{l}\text { Average for } \\
2020-2050 \\
\text { corresponding } \\
\text { to historical } \\
\text { harvest rate }\end{array}$ & $\begin{array}{l}\text { Equilibrium } \\
\text { corresponding } \\
\text { to natural pre- } \\
\text { suppression } \\
\text { disturbance } \\
\text { rate }\end{array}$ & $\begin{array}{c}\text { Historical } \\
\text { harvest }\end{array}$ & $\begin{array}{l}\text { Natural pre- } \\
\text { suppression } \\
\text { disturbance }\end{array}$ \\
\hline $\mathrm{NE}$ & Abitibi River Forest & 2435.90 & 129.21 & 376.41 & 1147.75 & 375.03 & 371.74 & 0.89 & 1.15 \\
\hline $\mathrm{NE}$ & Gordon Cosens Forest ${ }^{\mathrm{a}}$ & 1635.27 & 96.17 & 255.03 & 1079.52 & 256.44 & 272.42 & 1.12 & 0.00 \\
\hline $\mathrm{NE}$ & Hearst Forest & 1028.65 & 69.91 & 168.18 & 586.58 & 166.43 & 159.46 & 0.84 & 1.80 \\
\hline NE & Magpie Forest & 324.28 & 29.16 & 52.93 & 185.54 & 50.95 & 47.24 & 0.64 & 2.14 \\
\hline NE & Martel Forest & 957.92 & 71.85 & 147.52 & 685.58 & 151.46 & 143.50 & 0.43 & 1.46 \\
\hline NE & Nagagami Forest & 381.95 & 31.58 & 63.36 & 286.04 & 60.74 & 60.56 & 0.91 & 0.98 \\
\hline NE & Pic Forest & 1005.15 & 70.06 & 157.15 & 600.98 & 155.37 & 151.05 & 0.86 & 1.21 \\
\hline $\mathrm{NE}$ & Pineland Forest & 328.67 & 22.15 & 49.58 & 271.37 & 48.53 & 49.73 & 1.22 & 0.56 \\
\hline $\mathrm{NE}$ & Romeo Malette Forest & 476.99 & 32.52 & 74.82 & 398.28 & 74.78 & 76.76 & 1.22 & 0.69 \\
\hline $\mathrm{NE}$ & Timiskaming Forest & 993.54 & 71.83 & 152.24 & 1005.08 & 151.38 & 153.34 & 1.40 & 1.08 \\
\hline $\mathrm{NE}$ & Black Spruce Forest & 1120.43 & 69.29 & 163.15 & 773.13 & 166.47 & 172.20 & 1.12 & 0.45 \\
\hline NW & Caribou Forest & 540.04 & 53.19 & 96.58 & 288.74 & 94.04 & 81.37 & 0.54 & 2.79 \\
\hline NW & Crossroute Forest & 914.46 & 59.10 & 128.39 & 975.45 & 125.46 & 130.02 & 1.65 & 1.00 \\
\hline NW & Dog River-Matawin Forest & 729.54 & 53.60 & 113.33 & 783.89 & 112.78 & 110.71 & 1.46 & 1.95 \\
\hline NW & Dryden Forest & 124.15 & 9.79 & 19.08 & 152.48 & 18.63 & 17.84 & 1.56 & 2.45 \\
\hline NW & English River Forest & 833.93 & 69.40 & 132.89 & 634.89 & 132.89 & 125.27 & 0.91 & 2.01 \\
\hline NW & Kenogami Forest & 1638.87 & 89.42 & 250.55 & 873.70 & 250.24 & 247.26 & 0.98 & 1.29 \\
\hline NW & Kenora Forest & 579.90 & 46.69 & 89.24 & 118.81 & 89.42 & 81.47 & 0.25 & 2.47 \\
\hline NW & Lac Seul Forest & 761.02 & 59.27 & 120.48 & 444.58 & 117.52 & 111.23 & 0.75 & 2.08 \\
\hline NW & Lake Nipigon & 1334.11 & 107.06 & 220.04 & 517.51 & 220.97 & 206.97 & 0.48 & 1.96 \\
\hline NW & Lakehead Forest & 379.21 & 31.51 & 59.92 & 246.70 & 59.99 & 57.67 & 0.78 & 1.53 \\
\hline NW & Ogoki Forest & 915.72 & 59.09 & 147.62 & 280.01 & 141.42 & 133.23 & 0.47 & 1.67 \\
\hline NW & Red Lake Forest & 189.16 & 14.51 & 28.20 & 141.76 & 28.22 & 25.58 & 0.98 & 2.65 \\
\hline NW & Sapawe Forest & 211.98 & 17.47 & 32.87 & 133.48 & 32.75 & 31.45 & 0.76 & 1.59 \\
\hline NW & Trout Lake Forest & 787.12 & 70.83 & 130.58 & 535.24 & 127.36 & 121.50 & 0.76 & 1.62 \\
\hline NW & Wabigoon Forest & 553.41 & 43.26 & 83.05 & 665.36 & 80.06 & 76.30 & 1.54 & 2.29 \\
\hline NW & Whiskey Jack Forest & 725.35 & 53.45 & 106.27 & 319.38 & 107.74 & 97.24 & 0.60 & 3.27 \\
\hline NW & White River Forest & 504.48 & 40.89 & 77.57 & 310.31 & 77.20 & 75.38 & 0.75 & 1.22 \\
\hline \multirow[t]{2}{*}{ NW } & Whitefeather Forest & 896.88 & 75.01 & 137.88 & 0.00 & 142.80 & 131.40 & 0.00 & 1.50 \\
\hline & Total & 23308.08 & 1647.26 & 3634.93 & 14442.13 & 3617.06 & 3519.90 & 0.88 & 1.44 \\
\hline
\end{tabular}

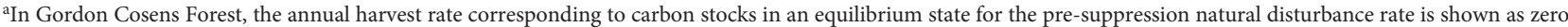
because the pre-suppression stocks exceed the average 2020-2050 stocks for the no harvest scenario. 